\title{
Determinan Pengungkapan Islamic Social Reporting (ISR) pada Bank Umum Syariah (BUS) di Indonesia (Determinants of Islamic Social Reporting (ISR) Disclosure at Islamic Commercial Banks in Indonesia)
}

\author{
Ikkama Arianugrahini, Egi Arvian Firmansyah* \\ IImu Ekonomi Islam, Universitas Padjadjaran, Bandung, Indonesia
}

This study aims to analyze the factors that affect the disclosure of Islamic Social Reporting (ISR) in the annual report of Islamic Commercial Banks (BUS) in Indonesia for the 2014-2018 period. The method used in selecting the sample in this study was purposive sampling using 55 samples which were determined based on the sample criteria in this study. Hypothesis testing in this study uses multiple linear regression analysis. ISR is evaluated based on content analysis by analyzing the annual reports of 11 Islamic Commercial Banks (BUS) in the 2014-2018 period. The results of this study indicate that, simultaneously, all independent variables have a positive effect on ISR. Firm size has a significant effect on ISR, while company age, profitability, leverage, and cost efficiency have no significant effect on ISR. It does not affect company age, profitability, leverage, and cost efficiency because these variables are not directly related to the ISR disclosure.

OPEN ACCESS ISSN 2503-3077 (Online) (online) ISSN 2503-3077 (print)

${ }^{*}$ Correspondence: Egi Arvian Firmansyah egi.firmansyah@unpad.ac.id

Received: 10 August 2020 Accepted: 10 September 2020 Published: 10 October 2020

Citation:

Arianugrahini I and Firmansyah EA (2020) Determinan Pengungkapan Islamic Social Reporting (ISR) pada

Bank Umum Syariah (BUS) di Indonesia (Determinants of Islamic Social Reporting (ISR) Disclosure at Islamic Commercial Banks in Indonesia).

Perisai : Islamic Banking and Finance Journal. 4:2. doi: 10.21070/perisai.v4i2.841
Keywords: Islamic Social Reporting, ISR, Company Age, Company Size, Profitability, Leverage, Cost Efficiency

Penelitian ini bertujuan menganalisis faktor-faktor yang mempengaruhi pengungkapan Islamic Social Reporting (ISR) pada laporan tahunan Bank Umum Syariah (BUS) di Indonesia periode 2014-2018. Metode yang digunakan dalam pemilihan sampel dalam penelitian ini adalah purposive sampling dengan menggunakan 55 sampel yang ditentukan berdasarkan kriteria sampel dalam penelitian ini. Pengujian hipotesis dalam penelitian ini menggunakan analisis regresi linier berganda. ISR dievaluasi berdasarkan content analysis dengan menganalisis laporan tahunan dari 11 Bank Umum Syariah (BUS) pada periode 2014-2018. Hasil penelitian ini menunjukkan bahwa, secara simultan, seluruh variabel independen berpengaruh positif terhadap ISR. Ukuran perusahaan berpengaruh signifikan terhadap ISR, sedangkan usia perusahaan, profitabilitas, leverage, dan efisiensi biaya tidak berpengaruh signifikan terhadap ISR. Tidak berpengaruhnya usia perusahaan, profitabilitas, leverage, dan efisiensi biaya tersebut disebabkan tidak berhubungan langsungnya variabel tersebut terhadap pengungkapan ISR.

Kata Kunci: Islamic Social Reporting, ISR, Usia Perusahaan, Ukuran Perusahaan, Profitabilitas, Efisiensi Biaya, Leverage 


\section{LATAR BELAKANG}

Tanggung jawab sosial perusahaan atau CSR (Corporate Social Responsibility) adalah salah satu dari beberapa tanggung jawab perusahaan terhadap pemangku kepentingan (Stakeholders) dan juga merupakan inti dari etika bisnis suatu perusahaan. Menurut Mulia (2009) dalam Prasetyoningrum and Kristin (2018), pengungkapan CSR ini memiliki peranan penting dalam perusahaan karena perusahaan hidup di lingkungan masyarakat dan aktivitasnya memiliki pengaruh sosial dan lingkungan, sehingga dalam pengungkapan tanggung jawab sosial digunakan sebagai alat manajerial untuk menghindari konflik sosial dan lingkungan.

Program CSR yang tercantum dalam pengungkapan CSR dapat menjadi peluang strategi untuk mendapatkan keuntungan bagi perusahaan. Serta Program CSR yang tercantum dalam pengungkapan CSR tersebut dapat menunjang pertumbuhan perusahaan dan pembangunan berkelanjutan (Sustainable Development). CSR memang tidak memberikan hasil secara keuangan dalam jangka waktu pendek. Namun, CSR akan memberikan hasil baik langsung maupun tidak langsung pada keuangan perusahaan di masa mendatang.

Dengan demikian, apabila perusahaan melakukan program-program CSR, diharapkan keberlanjutan perusahaan akan terjamin dengan baik. Oleh karena itu, programprogram CSR lebih tepat apabila digolongkan sebagai investasi dan harus menjadi strategi bisnis dari suatu perusahaan. Dengan masuknya program CSR sebagai bagian dari strategi bisnis, maka akan dengan mudah bagi unit-unit usaha yang berada dalam suatu perusahaan untuk mengimplementasi kan rencana kegiatan dari program CSR yang dirancangnya. Dilihat dari sisi pertanggung jawaban keuangan atas setiap investasi yang dikeluarkan dari program CSR menjadi lebih jelas dan tegas, sehingga pada akhirnya keberlanjutan yang diharapkan akan dapat terimplementasi berdasarkan harapan semua stakeholder Lestari (2013).

Selain itu masih banyak pengguna bank syariah belum menyadari akan pentingnya menggunakan jasa layanan bank yang sesuai dengan prinsip syariah, khususnya bagi warga negara Indonesia yang mayoritas warganya memeluk agama Islam. Tercatat pada Badan Pusat Statistik yaitu sebanyak 207.176.162 jiwa warga Indonesia yang memeluk agama Islam. Hal tersebut semakin mendorong pertumbuhan jumlah unit Bank Umum Syariah (BUS) di Indonesia yang terdaftar dalam OJK. Tercatat pada tahun 2014 dan 2015 berjumlah 12 unit Bank Umum Syariah, lalu tahun 2016 dan 2017 berjumlah 13 unit Bank Umum Syariah, kemudian menjadi berjumlah 14 unit Bank Umum Syariah (BUS) pada tahun 2018.Namun Bank Umum Syariah tersebut masih diragukan dalam kesesuaian syariah dalam produk serta penyaluran dana dalam laporan keuangan maupun kegiatan bank syariah tersebut.

Sehingga hal-hal tersebut mendorong lahirnya CSR atau pengungkapan tanggung jawab sosial dalam ekonomi syariah yang disebut dengan Islamic Social Reporting (ISR). Indeks ISR (Islamic Social Reporting) merupakan bentuk standar pela- poran dari pengungkapan CSR pada perusahaan perbankan syariah. Indeks ini telah dirancang oleh Ross Haniffa tahun 2002 Gustani (2013). Berikutnya indeks ini dikembangkan kembali oleh peneliti selanjutnya untuk dapat merelevansikan item-item yang terdapat didalamnya.

Sebagai perusahaan yang berbasis Islam, sudah sepatutnya bank syariah memperhatikan lingkungan dan masyarakat sekitar sebagai bentuk kepedulian dan tanggung jawab terhadap umat. Menurut Haniffa and Cooke (2002), dalam penelitiannya menyatakan bahwa adanya keterbatasan dalam pelaporan sosial dalam konvensional, sehingga ia mengemukakan kerangka konseptual Islamic Social Reporting berdasarkan ketentuan syariah, yang tidak hanya membantu pengambilan keputusan untuk pihak muslim tetapi juga membantu perusahaan dalam melakukan pemenuhan kewajibannya terhadap Allah. Melalui indeks ISR ini, para calon nasabah juga stakeholders maupun shareholders dapat melihat kinerja dari perbankan syariah yang ada. Sesuai dengan UU No. 21 tahun 2008 pasal 7 "Bentuk badan hukum bank syariah adalah Perseroan Terbatas", sehingga dalam hal tanggung jawab sosial dan lingkungan, bank syariah harus mengacu pada UU No. 40 tahun 2007 pasal 74 tentang Perseroan Terbatas (PT). Dalam Undang-Undang tersebut memiliki aturan bahwa setiap Perseroan Terbatas wajib memberikan laporan tahunan yang didalamnya terdapat laporan pelaksanaan tanggung jawab sosial dan lingkungan. Jika tidak memberikan laporan sebagaimana dalam aturan tersebut maka akan dikenakan sanksi sesuai dengan ketentuan peraturan perundang-undangan.

Dalam penelitian yang dilakukan oleh Qoyum et al. (2017) meneliti elemen Good Corporate Governance (GCG) dan ukuran perusahaan terhadap pengaruhnya kepada pengungkapan tangung jawab sosial atau CSR dengan pendekatan Islamic Social Reporting (ISR) yang dimana dari penelitian tersebut dikatakan bahwa hanya elemen GCG yang tidak memiliki pengaruh terhadap pengungkapan CSR, juga dalam penelitian tersebut disarankan untuk menggunakan sampel dan variabel tambahan lain yang dapat mempengaruhi pengungkapan CSR diluar penelitian tersebut.

Berdasarkan latar belakang yang telah dipaparkan sebelumnya, maka penelitian ini bertujuan untuk mengetahui:

1. Apakah terdapat pengaruh dari usia perusahaan terhadap pengungkapan Islamic Social Reporting (ISR)?

2. Apakah terdapat pengaruh dari ukuran perusahaan terhadap pengungkapan Islamic Social Reporting (ISR)?

3. Apakah terdapat pengaruh dari profitabilitas terhadap pengungkapan Islamic Social Reporting (ISR)?

4. Apakah terdapat pengaruh dari leverage terhadap pengungkapan Islamic Social Reporting (ISR)?

5. Apakah terdapat pengaruh dari efisiensi biaya terhadap pengungkapan Islamic Social Reporting (ISR)?

6. Apakah terdapat pengaruh dari ukuran perusahaan, profitabilitas, leverage,efisiensi biaya dan usia perusahaan terhadap Islamic Social Reporting (ISR) ? 


\section{TUJUAN PENELITIAN}

Berdasarkan saran dari penelitian terdahulu yang dilakukan oleh Qoyum et al. (2017), maka penulis bertujuan menambahkan faktor-faktor lainnya seperti usia perusahaan, ukuran perusahaan, profitabilitas,leverage, dan efisiensi biaya untuk menganalisis faktor-faktor yang dapatmempengaruhi pengungkapan Islamic Social Reporting (ISR) pada laporan tahunan Bank Umum Syariah (BUS) di Indonesia periode 20142018.

\section{TINJAUAN PUSTAKA}

\section{Teori Legitimasi}

Teori legitimasi merupakan teori yang berhubungan langsung dengan kinerja keuangan perusahaan. Dalam teori ini dikatakan bahwa jika suatu perusahaan tidak dapat mengelola reputasi perusahaan nya dengan baik, maka akan terjadi penurunan pada kinerja perusahaan tersebut. Salah satu upaya yang dilakukan perusahaan dalam mengelola legitimasi agar efektif adalah dengan melakukan strategi legitimasi dan pengungkapan terkait dengan CSR. Hal ini sejalan dengan konsep trilogi dalam ajaran Islam mengenai hubungan manusia dengan Tuhan (Q.S Adz Dzariyat [51]: 56), hubungan antar sesama manusia (Q.S Al Baqarah [2]: 177), dan hubungan antara manusia dengan alam (Q.S Hud [11]: 61 dan Q.S Al Araf [7]: 56). Hal ini berarti bahwa dalam aktivitas apapun, manusia harus tetap memiliki keseimbangan dalam berhubungan dengan Tuhan, manusia dan lingkungan (Qoyum et al., 2017).

\section{Teori Stakeholders}

Dalam Islam, menurut Mirakhor and Iqbal (2008), stakeholder adalah mereka yang kepemilikannya dipertaruhkan atau terkena risiko sebagai akibat dari tindakan perusahaan yang sengaja atau tidak disengaja. Keberadaan stakeholder sangat penting bagi perbankan syariah (dan lembaga keuangan syariah lainnya). Oleh karena itu, Indeks ISR tidak hanya memuat informasi terkait keuangan, tetapi juga etika, agama, dan nilai luhur lainnya seperti kepedulian pada masyarakat dan lingkungan. Hal ini untuk memenuhi seluruh kepentingan stakeholder.

\section{Islamic Social Reporting (ISR)}

Berdasarkan hasil penelitian terdahulu, ISR bukan hanya sekadar pelaporan atau pengungkapan sosial untuk masyarakat terkait dengan peran perusahaan dalam ekonomi dan pemenuhan ekspektasi stakeholders terhadap sekitarnya. Namun dalam pengungkapan ISR juga mencakup pada perspektif spiritual yang menggambarkan prinsip-prinsip syariah (Haniffa and Cooke (2002) ; Maali et al. (2006) ; Othman et al. (2009)). Berikut rumus yang digunakan untuk mengukur tingkat pengungkapan ISR pada laporan tahunan suatu perusahaan dalam penelitian ini:

$$
\text { Disclosure level }=\frac{\text { Number of complied item }}{\text { Maximum total score }}
$$

\section{Usia Perusahaan}

Usia perusahaan merupakan faktor penting dalam mempengaruhi tingkat pengungkapan. Usia perusahaan menunjukkan lamanya periode suatu perusahaan tersebut telah ada atau beroperasi pada suatu industri. Usia perusahaan dapat dihitung sejak perusahaan tersebut didirikan pertama kali. Perusahaan yang memiliki usia lebih tua diasumsikan akan memberikan pengungkapan informasi yang lebih banyak dalam laporan tahunannya dibandingkan dengan perusahaan dengan usia yang lebih muda. Haniffa and Cooke (2002) mengatakan bahwa perusahaan dengan usia yang lebih tua memiliki kemungkinan akan memberikan pengungkapan yang lebih luas dalam memenuhi tanggung jawab kepatuhan perusahaan terhadap aturan dan masyarakat.

\section{Ukuran Perusahaan}

Ukuran perusahaan merupakan salah satu ukuran penting yang banyak digunakan untuk menjelaskan variasi pengungkapan dalam laporan tahunan suatu perusahaan. Moh.Zain, 1999 dan Ousama \& Fatima, 2006 dalam Othman et al. (2009) dalam penelitiannya mengatakan bahwa berdasarkan agency theory, perusahaan besar yang diukur dengan menggunakan total aset nya akan memberikan tingkat pengungkapan yang lebih tinggi dalam mewakili diri mereka sebagai warga negara yang baik dalam menyebarluaskan tanggung jawab sosial mereka dan menemukan bahwa ukuran perusahaan mempengaruhi keputusan mereka untuk memberikan tingkat pengungkapan dalam laporan tahunan. Sehingga total aset dinilai dapat menggambarkan apakah suatu Bank Umum Syariah/perusahaan termasuk ke dalam kategori perusahaan dengan ukuran besar atau kecil. Berikut rumus yang digunakan dalam penelitian ini untuk meghitung ukuran perusahaan :

total asset $=$ asset lancar + asset tetap $/$ SIZE $=\mathrm{Ln}$ (total assets)

\section{Profitabilitas}

Menurut Kasmir (2016) rasio profitabilitas menjelaskan ukuran tingkat efektifitas manajemen suatu perusahaan. Untuk mengukur rasio profitabilitas dapat diukur melalui Gross Profit Margin, Net Profit Margin, Return On Asset (ROA), Return on Equity Ratio (ROE), Return on Investment (ROI), Earning Per Share (EPS). Nilai profitabilitas bank umum syariah dalam penelitian ini diukur menggunakan nilai rasio Return On Asset (ROA). Rasio Return On Asset (ROA) merupakan rasio yang menunjukkan kemampuan perusahaan untuk menghasilkan laba setelah adanya pajak dengan menggunakan seluruh aktiva yang dimiliki. Rasio ini penting untuk pihak manajemen perusahaan mengevaluasi efektifitas dan efisiensi manajemen perusahaan dalam mengelola aktiva perusahaan. Semakin 
tinggi nilai ROA maka suatu bank umum syariah memiliki peluang yang besar untuk dapat meningkatkan laju pertumbuhannya. Berikut rumus yang digunakan dalam penelitian ini untuk meghitung profitabilitas/ROA:

$$
R O A=\frac{\text { Laba Setelah Pajak }}{\text { Asset }} \times 100 \%
$$

\section{Leverage}

Menurut Sawir (2005), "rasio leverage digunakan untuk mengukur tingkat solvabilitas suatu perusahaan". Dapat diartikan, leverage adalah rasio yang digunakan untuk mengukur seberapa jauh perusahaan menggunakan hutang untuk meningkatan keuntungan perusahaan dan memenuhi kewajiban finansial perusahaannya dalam jangka panjang dan jangka pendek seandainya dalam kondisi dilikuidasi Kasmir (2016).

Untuk mengukur rasio leverage dapat diukur melalui Debt to Assets Ratio (DAR) dan Debt to Equity Ratio (DER). Debt to Assets Ratio (DAR) merupakan rasio hutang yang digunakan untuk mengukur perbandingan antara total hutang dengan total aktiva. Melalui DAR dapat melihat seberapa besar pengaruh hutang perusahaan terhadap pengelolaan aktiva perusahaan tersebut. Sedangkan Debt to Equity Ratio (DER) merupakan rasio yang diukur dengan membandingkan seluruh hutang dengan jumlah ekuitas perusahaan. Melalui DER dapat menunjukkan total dana yang diberikan peminjam (kreditor) kepada pemilik perusahaan. Jenis rasio yang digunakan dalam penelitian ini untuk mengukur leverage yaitu menggunakan Debt to Equity Ratio (DER). Semakin besar jumlah DER maka dapat dikatakan perusahaan memiliki risiko yang semakin besar terhadap likuiditas perusahaannya.

Berikut rumus yang digunakan dalam penelitian ini untuk meghitung Leverage/DER:

$$
\text { DER }=\frac{\text { Total Debt }}{\text { Total Equity }} \times 100 \%
$$

\section{Efisiensi Biaya}

Efisiensi biaya atau rasio $\mathrm{BOPO}$ merupakan rasio biaya operasional yang digunakan untuk mengukur tingkat efisiensi dan kemampuan dari suatu bank dalam melakukan kegiatan operasinya (Dendawijaya, 2009). Semakin rendah nilai BOPO dari suatu bank maka akan semakin efisien bank tersebut dalam mengelola biaya operasionalnya, dengan dilakukannya efisiensi biaya maka keuntungan yang diperoleh bank akan semakin meningkat. Jika nilai rasio BOPO semakin kecil maka akan lebih baik. Hal ini karena bank tersebut akan dapat menutup beban operasionalnya dengan pendapatan operasionalnya. Berikut rumus yang digunakan dalam penelitian ini untuk meghitung Efisiensi Biaya/BOPO:

$$
B O P O=\frac{\text { Beban Operasional }}{\text { Pendapatan Operasional }} \times 100 \%
$$

\section{METODOLOGI}

Jenis penelitian ini adalah penelitian kuantitatif dengan jenis data yang digunakan adalah data sekunder dan populasi yang digunakan adalah seluruh Bank Umum Syariah (BUS) yang ada di Indonesia, yaitu berjumlah 14 unit bank yang terdaftar dalam Otoritas Jasa Keuangan. Jumlah sampel terpilih yaitu 11 Bank Umum Syariah menggunakan metode pemilihan sampel yaitu purposive sampling dengan kriteria sebagai berikut:

1. Bank syariah yang telah mempublikasikan laporan tahunan mulai 31 Desember 2014 hingga 31 Desember 2018 secara berturut-turut

2. Bank syariah yang mengungkapkan informasi item Islamic Social Reporting dalam laporan tahunannya

3. Bank syariah yang memberikan informasi tentang CSR dan yang berkaitan dengan variabel dalam laporan tahunan periode 2014-2018.

Pengumpulan data menggunakan metode dokumentasi dengan mengambil data melalui laporan tahunan dan laporan GCG perbankan syariah yang telah dipublikasi pada tahun 2014-2018.

Variabel dependen dalam penelitian ini adalah tingkat pengungkapan Islamic Social Reporting (ISR) di Indonesia pada laporan tahunan diukur melalui nilai Indeks ISR. Nilai ini didapat dari hasil content analysis. Content analysis dalam penelitian ISR merupakan metode penelitian yang digunakan sebelumnya oleh Othman et al. (2009) yang kemudian indeks ISR tersebut dikembangkan kembali oleh Fitria and Hartanti (2010) yang terdiri dari 58 item pengungkapan. ISR yang digunakan pada penelitian ini adalah 6 kategori, yaitu investasi dan keuangan, produk dan jasa, tenaga kerja, sosial, lingkungan dan tata kelola organisasi. Variabel independen dalam penelitian ini adalah usia perusahaan, ukuran perusahaan, profitabilitas, leverage, efisiensi biaya.

Metode analisis data dalam penelitian ini menggunakan metode analisis konten (Content Analysis) dan analisis regresi linear berganda (Multilinear Regression Analysis). Content analysis atau analisis konten merupakan metode pengumpulan data penelitian melalui observasi dan dokumentasi (jurnal, pers, dan laporan). Tujuan dari analisis konten adalah mengidentifikasi karakteristik atau spesifikasi informasi yang terkandung dalam suatu dokumen sehingga menghasilkan sebuah penjelasan atau deskripsi yang objektif dan sistematis. Dalam melakukan analisis konten sesuai dengan penelitian Qoyum et al. (2017) untuk mendapatkan nilai total dari indeks ISR, maka akan dilakukan dengan scoring, yaitu diberikan nilai 1 pada tiap item jika terdapat pengungkapan tersebut pada laporan tahunan tiap bank di setiap tahunnya, kemudian akan diberikan nilai 0 jika tidak terdapat pengungkapan dalam laporan tahunan tiap bank pada tahunnya. Sedangkan untuk analisis regresi linear berganda adalah analisis yang digunakan untuk mengukur pengaruh/hubungan antara lebih dari satu variabel independent terhadap variabel dependen. Analisis ini juga dilakukan dengan mengestimasi dan memprediksi nilai 
rata-rata variabel dependen atas nilai variabel independent yang diketahui.

Berdasarkan model estimaasi dari hasil analisis regresi berganda yang telah dilakukan, maka persamaan regresi yang terbentuk adalah:

$$
\begin{aligned}
& \text { ISR }=\alpha+\beta 1 \text { Age }+\beta 2 \text { SIZE }+\beta 3 \text { ROA }+\beta 4 \text { DER }+\beta 5 \text { BOPO } \\
& +\varepsilon \\
& \text { ISR }=-1.699+0,02 \mathrm{AGE}+0,071 \mathrm{SIZE}+0,003 \mathrm{ROA}+ \\
& 0,004 \mathrm{DER}+0,000 \mathrm{BOPO}+\varepsilon
\end{aligned}
$$

\section{HASIL DAN PEMBAHASAN}

Penelitian ini bertujuan untuk mengetahui serta menganalisis pengaruh umur perusahaan (AGE), ukuran perusahaan (SIZE), profitabilitas (ROA), leverage (DER) dan efisiensi biaya (BOPO) terhadap Islamic Social Reporting (ISR) pada Bank Umum Syariah (BUS) di Indonesia[A1] . Dengan menggunakan metode penelitian studi pustaka, telah terpilih 11 bank umum syariah yang memenuhi kriteria sampel penelitian.

Untuk dapat membuat indeks Islamic Social Reporting, penelitian ini menggunakan metode content analysis yang dilakukan dengan membaca dan meneliti setiap item pengungkapan ISR yang tercantum dalam laporan keuangan/laporan tahunan yang telah dipublikasi oleh tiap bank umum syariah pada periode tahun 2014-2018. Hal tersebut juga dilakukan untuk mengetahui seberapa luas tingkat pengungkapan tanggung jawab sosial yang telah dilaksanakan oleh bank umum syariah. Setelah melakukan content analysis pada penelitian ini, total skor indeks ISR dari 11 bank umum syariah mengalami peningkatan dari tahun 2014 hingga 2018. Hal ini memberikan penjelasan bahwa dalam kegiatan operasionalnya, para bank umum syariah sudah melakukan peningkatan dalam menyampaikan tanggung jawab sosialnya yang sesuai dengan prinsip syariah.

Dari hasil content analysis yang dilakukan pada bank umum syariah periode 2014-2018 dapat diketahui bahwa tema sosial adalah tema yang paling banyak diungkapkan oleh para bank umum syariah yang item-itemnya berisi sedekah/donasi, wakaf, zakat, pendirian sekolah, bantuan pada sekolah, beasiswa, bantuan kesehatan, pemberdayaan ekonomi, kepedulian pada anak yatim piatu, pembangunan masjid, dll. Berbeda dengan tema lingkungan, dimana item ISR yang terdapat dalam tema ini seperti konservasi lingkungan, kegiatan menanggulangi pemanasan global, audit lingkungan dan kebijakan manajemen lingkungan dimana dalam tema ini pula item yang paling sedikit diungkapkan karena bank tidak berhubungan langsung kegiatannya dengan lingkungan.

Di bawah ini adalah hasil uji signifikansi dan analisis hipotesis keterkaitan setiap variabel independent dengan variabel pengungkapan ISR:

\section{Pengaruh Usia Perusahaan/Age terhadap Pengungkapan ISR}

Usia perusahaan merupakan faktor penting dalam mempengaruhi tingkat pengungkapan. Perusahaan dengan usia perusahaan yang lebih tua memungkinkan akan memberikan pengungkapan informasi yang lebih banyak dalam laporan tahunannya dibandingkan dengan perusahaan dengan usia yang lebih muda.

[Table 1 about here.]

Sumber: data diolah dengan SPSS, 2019

Hasil penelitian ini mendukung hasil penelitian yang dilakukan oleh Lestari (2013) dimana dalam penelitian tersebut dibuktikan bahwa usia perusahaan tidak berpengaruh terhadap pengungkapan ISR karena bank syariah yang berada di Indonesia relatif baru. Namun hal ini berbeda dengan penelitian (Santoso, 2018) dimana variabel usia perusahaan atau Age memiliki pengaruh yang signifikan pada pengungkapan ISR, dan juga bertentangan dengan hasil penelitian dari Alanezi et al. (2012) dimana dalam penelitian tersebut disebutkan bahwa peningkatan usia perusahaan akan meningkatkan jumlah pengungkapan sosial perusahaan.

\section{Pengaruh Ukuran Perusahaan /SIZE terhadap Pengungkapan ISR}

Ukuran perusahaan adalah salah satu ukuran penting yang banyak digunakan untuk memaparkan variasi pengungkapan dalam laporan tahunan suatu perusahaan. Moh.Zain, 1999 dan Ousama \& Fatima, 2006 dalam (Othman et al., 2009) dalam penelitiannya mengatakan bahwa perusahaan besar yang diukur dengan menggunakan total asset nya akan memberikan tingkat pengungkapan yang lebih tinggi dalam mewakili diri mereka sebagai warga negara yang baik dalam menyebarluaskan tanggung jawab sosial mereka dan menemukan bahwa ukuran perusahaan mempengaruhi keputusan mereka untuk memberikan tingkat pengungkapan dalam laporan tahunan.

[Table 2 about here.]

Sumber: data diolah dengan SPSS, 2019

\section{Pengaruh Profitabilitas/ROA terhadap Pengungkapan ISR}

Rasio profitabilitas merupakan rasio untuk mengukur kemampuan perusahaan dalam memperoleh laba dalam kaitannya dengan penjualan, total aktiva maupun modal saham tertentu. Dalam perspektif islam, perusahaan harus bersedia memberikan semua pengungkapan atau pelaporan secara penuh tanpa melihat kembali apakah bank umum syariah memberikan keuntungan atau tidak. Perusahaan dengan nilai profitabilitas yang tinggi memungkinkan untuk mengungkap- 
kan informasi lebih lengkap dibandingkan dengan perusahaan yang hanya memberikan sedikit informasi atau informasi yang kurang lengkap. Nilai profitabilitas bank umum syariah dalam penelitian ini diukur menggunakan nilai rasio Return On Asset (ROA). Semakin tinggi nilai ROA maka suatu bank umum syariah memiliki peluang yang besar untuk dapat meningkatkan laju pertumbuhannya. Meningkatnya keuntungan yang didapatkan oleh suatu perusahaan atau bank umum syariah, maka perusahaan akan dapat menanggung biaya lebih tinggi untuk memberikan pengungkapan laporan sosial yang lebih meluas.

[Table 3 about here.]

Sumber: data diolah dengan SPSS, 2019

Hasil penelitian ini mendukung penelitian yang dilakukan oleh (Purwani et al., 2018; Santoso, 2018; Sunarsih and Ferdiansyah, 2016) dalam ketiga penelitian tersebut disebutkan bahwa profitabilitas suatu perusahaan tidak memiliki pengaruh dalam pengungkapan ISR, hal tersebut karena bahwa perusahaan memiliki perspektif yang berbeda dengan ISR. Namun hal ini bertentangan dengan hasil penelitian Lestari (2013) dan Amyulianthy et al. (2019) dalam kedua penelitian tersebut dikatakan bahwa profitabilitas suatu perusahaan memiliki pengaruh terhadap pengungkapan ISR yang dilihat melalui nilai ROA perusahaan tersebut.

\section{Pengaruh Leverage/DER terhadap Pengungkapan ISR}

Menurut Sawir (2005:13), "rasio leverage digunakan untuk mengukur tingkat solvabilitas suatu perusahaan". leverage adalah rasio yang digunakan untuk mengukur seberapa jauh perusahaan menggunakan hutang untuk meningkatan keuntungan perusahaan dan memenuhi kewajiban finansial perusahaannya dalam jangka panjang dan jangka pendek seandainya dalam kondisi

[Table 4 about here.]

Sumber: data diolah dengan SPSS, 2019

Dalam hasil pengujian hipotesis dalam penelitian ini menunjukkan bahwa nilai signifikansi untuk leverage adalah sebesar 0,581 dan nilai koefisien regresi adalah 0,004. Disebabkan nilai signifikansi lebih besar

Hasil penelitian ini mendukung penelitian yang dilakukan oleh Purwani et al. (2018) ; Riyani (2018) dalam penelitiannya dibuktikan bahwa leverage tidak memiliki pengaruh terhadap pengungkapan ISR. Namun berbeda dengan penelitian yang dilakukan oleh Amyulianthy et al. (2019) dalam penelitiannya dikatakan bahwa leverage dalam perusahaan memiliki pengaruh terhadap pengungkapan ISR.

\section{Pengaruh Efisiensi Biaya/BOPO terhadap Pengungkapan ISR}

Efisiensi biaya atau rasio BOPO merupakan rasio biaya operasional yang digunakan untuk mengukur tingkat efisiensi dan kemampuan dari suatu bank dalam melakukan kegiatan operasinya (Dendawijaya, 2009). Semakin rendah nilai BOPO dari suatu bank maka akan semakin efisien bank tersebut dalam mengelola biaya operasionalnya, dengan dilakukannya efisiensi biaya maka keuntungan yang diperoleh bank akan semakin meningkat. Jika nilai rasio BOPO semakin kecil maka akan lebih baik karena bank tersebut akan dapat menurup beban operasionalnya dengan pendapatan operasionalnya.

[Table 5 about here.]

Sumber: data diolah dengan SPSS, 2019

Hasil penelitian ini mendukung penelitian yang dilakukan oleh Prasetyoningrum and Kristin (2018), dalam hasil penelitian tersebut membuktikan bahwa variabel BOPO memiliki pengaruh yang negative dan tidak signifikan dalam pengaruhnya terhadap pengungkapan ISR pada perbankan syariah di Indonesia.

\section{Pengaruh Usia Perusahaan, Ukuran Perusahaan, Profitabilitas, Leverage dan Efisiensi Biaya secara Simultan terhadap ISR}

[Table 6 about here.]

Hasil analisis dari penelitian ini menunjukkan bahwa signifikansi pada hasil uji F kurang dari 5\% yaitu 0,000 dan nilai F hitung nya adalah 18,247 > F table 2,40 sehingga dapat disimpulkan variabel AGE, SIZE, ROA, DER dan BOPO terbukti berpengaruh secara simultan terhadap pengungkapan ISR. Sedangkan dari hasil analisis uji koefisien determinasi diketahui bahwa nilai Adjusted R Square sebesar 0,615 sehingga dapat disimpulkan bahwa pengaruh variabel AGE, SIZE, ROA, DER dan BOPO secara simultan terhadap variabel $Y$ adalah sebesar $61,5 \%$ dan sisanya sebesar $38,5 \%$ didipengaruhi oleh variabel lain di luar model penelitian ini.

Berdasarkan hasil uji hipotesis yang dilakukan pada penelitian ini dapat disimpulkan bahwa secara simultan, variabel AGE, SIZE, ROA, DER dan BOPO secara simultan terbukti berpengaruh signifikan terhadap pengungkapan ISR. Mengacu pada terori legitimasi maka hal ini dapat karena seiring dengan usia Bank Umum Syariah yang bertambah, kinerja perusahaan yang semakin baik, seperti ukuran perusahaan Bank Umum Syariah yang bertambah, jumlah rasio ROA, DER dan BOPO dari Bank Umum Syariah yang semakin kecil setiap tahunnya dalam menjalankan ke efektifan perusahaan dalam beroperasi setiap tahunnya membuat perusahan harus memegang tanggung jawab yang besar pada pengungkapan ISR. Hal ini pun sesuai pula dengan teori stakeholders, dimana Bank Umum Syariah harus dapat memberikan pelaporan kepada para stakeholders terkait kebutuhan pengungkapan ISR yang harus terus lebih luas setiap tahunnya demi kepentingan stakeholders. 


\section{KESIMPULAN}

Penelitian ini memiliki tujuan untuk melihat seberapa besar pengaruh faktor usia perusahaan, ukuran perusahaan, profitabilitas, leverage, dan efisiensi biaya pada suatu bank umum syariah terhadap pengungkapan tanggung jawab sosial islam IIslamic Social Reporting (ISR). Berdasarkan data yang didapatkan dan pengujian yang telah dilakukan dengan menggunakan content analysis, uji regresi linear berganda, uji ketepatan model dan uji statistic T serta pembahasan pada bab sebelumnya, maka dapat diambil kesimpulan sebagai berikut.

1. Hasil pengujian dalam penelitian ini menyatakan bahwa usia perusahaan, ukuran perusahaan, profitabilitas, leverage, dan efisiensi biaya secara simultan berpengaruh terhadap pengungkapan Islamic Social Reporting (ISR).

2. Hasil pengujian dalam penelitian ini menyatakan bahwa secara parsial hanya ukuran perusahaan/SIZE yang dapat mempengaruhi pengungkapan Islamic Social Reporting (ISR). Hasil ini memiliki kesamaan dengan hasil penelitian yang dilakukan oleh Amyulianthy et al. (2019), Lestari (2013), Purwani et al. (2018), Santoso (2018), Sunarsih and Ferdiansyah (2016).

3. Hasil pengujian dalam penelitian ini menyatakan bahwa secara parsial, usia perusahaan/AGE tidak memiliki pengaruh terhadap pengungkapan Islamic Social Reporting

\section{REFERENCES}

Alanezi, F. S., Alfaraih, M. M., Alrashaid, E. A., and Albolushi, S. S. (2012). Dual/joint auditors and the level of compliance with international financial reporting standards (IFRS-required disclosure). Journal of Economic and Administrative Sciences 28, 109-129. doi: 10.1108/10264111211248402.

Amyulianthy, R., Azizah, W., and Satria, I. (2019). Islamic Social Reporting in Shariah Banks in Indonesia. Review of Integrative Business \& Economics Research 9, 171-182.

Dendawijaya, L. (2009). Manajemen Perbankan (Jakart: Ghalia Indonesia).

Fitria, S. and Hartanti, D. (2010). Studi Perbandingan Pengungkapan Berdasarkan Global Reporting Initiative Indeks Dan Islamic Sosial Reporting Indeks.

Gustani (2013). Islamic Social Reporting (ISR) sebagai Model Pelaporan CSR Institusi Bisnis Syariah. https://www.gustani.id/2013/02/indeks-isr-sebagai-modelpelaporan-csr_16.html.

Haniffa, R. M. and Cooke, T. E. (2002). Culture, Corporate Governance and Disclosure in Malaysian Corporations. Abacus 38, 317-349. doi: 10.1111/1467-6281. 00112.

Kasmir (2016). Analisis Laporan Keuangan (Jakarta: Raja Grafindo Persada).

Lestari, P. (2013). Determinants Of Islamic Social Reporting In Syariah Banks: Case Of Indonesia. International Journal of Business and Management Invention ISSN 2, 28-34.

Maali, B., Casson, P., and Napier, C. (2006). Social reporting by islamic banks. Abacus 42, 266-289. doi: 10.1111/j.1467-6281.2006.00200.x.

Mirakhor, A. and Iqbal, Z. (2008). Pengantar Keuangan Islam Teori dan Praktik (Jakarta: Kencana)

Othman, R., Thani, A. M., and Ghani, E. K. (2009). Determinants of Islamic Social Reporting Among Top Shariah-Approved Companies in Bursa Malaysia. Research Journal of International Studies 12, 4-20.

Prasetyoningrum, A. and Kristin (2018). Leverage, Efisiensi Biaya , Dan Umur Perusahaan Terhadap Islamic Social Reporting ( Isr ) Pada Perbankan Syariah Di Indonesia. Journal of Islamic Banking and Finance 2, 147-162.
(ISR). Hasil ini memiliki kesamaan dengan hasil penelitian yang dilakukan oleh Lestari (2013), namun bertentangan dengan hasil penelitian Alanezi et al. (2012), Santoso (2018).

4. Hasil pengujian dalam penelitian ini menyatakan bahwa secara parsial, profitabilitas/ROA tidak memiliki pengaruh terhadap pengungkapan Islamic Social Reporting (ISR). Hasil penelitian ini memiliki kesamaan dengan hasil penelitian yang dilakukan oleh Purwani et al. (2018), Santoso (2018), Sunarsih and Ferdiansyah (2016), namun bertentangan dengan hasil penelitian penelitian Amyulianthy et al. (2019), Lestari (2013).

5. Hasil pengujian dalam penelitian ini menyatakan bahwa secara parsial, leverage/DER tidak memiliki pengaruh terhadap pengungkapan Islamic Social Reporting (ISR). Hasil penelitian ini memiliki kesamaan dengan hasil penelitian yang dilakukan oleh Purwani et al. (2018) dan Riyani (2018), namun bertentangan dengan penelitian Amyulianthy et al. (2019).

6. Hasil pengujian dalam penelitian ini menyatakan bahwa secara parsial, efisiensi biaya/BOPO tidak memiliki pengaruh terhadap pengungkapan Islamic Social Reporting (ISR). Hasil penelitian ini memiliki kesamaan dengan hasil penelitian yang dilakukan oleh Prasetyoningrum and Kristin (2018).
Purwani, T., Nurlaela, and Siti, A. W. (2018). The Influence of Company Size, Profitability, Liquidity, Leverage and Tax Avoidance Disclosure Against the Islamic Social Reporting on Companies Listed On The Indonesian Stock Index of Sharia. The 2nd International Conference on Technology, 39-47.

Qoyum, A., Mutmainah, L., Setyono, J., and Qizam, I. (2017). The Impact of Good Corporate Governance, Company Size nn Corporate Social Responsibility Disclosure : Case Study of Islamic Banking in Indonesia. Iqtishadia 10, 130-159.

Riyani, D. (2018). The Effect of Corporate Governance, Leverage, and Liquidity on Islamic Social Reporting (ISR) Disclosure in Islamic Commercial Banks in Indonesia. The Indonesian Accounting Review 8, 121-121. doi: 10.14414/tiar. v8i2.1628.

Santoso, N. (2018). State-of-the-Art Theories and Empirical Evidence. State-ofthe-Art Theories and Empirical Evidence. https://doi.org/10.1007/978-981-106926-0.

Sawir, A. (2005). Dasar-dasar Analisis Laporan Keuangan dan Perencanaan Keuangan Perusahaan (Jakarta: PT Gramedia Pustaka Utama).

Sunarsih, U. and Ferdiansyah, F. (2016). Determinants of The Islamic Social Reporting Disclosure. Al-Iqtishad: Journal of Islamic Economics 9, 69-80. doi: 10.15408/aiq.v9i1.3771.

Conflict of Interest Statement: The authors declare that the research was conducted in the absence of any commercial or financial relationships that could be construed as a potential conflict of interest.

Copyright (C) 2020 Arianugrahini and Firmansyah. This is an open-access article distributed under the terms of the Creative Commons Attribution License (CC BY). The use, distribution or reproduction in other forums is permitted, provided the original author(s) and the copyright owner(s) are credited and that the original publication in this journal is cited, in accordance with accepted academic practice. No use, distribution or reproduction is permitted which does not comply with these terms. 


\section{LIST OF TABLES}

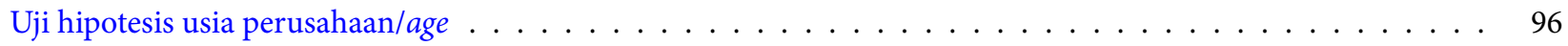

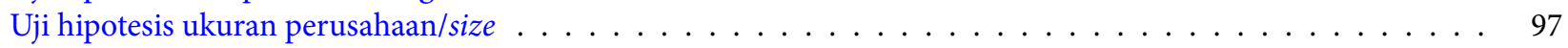

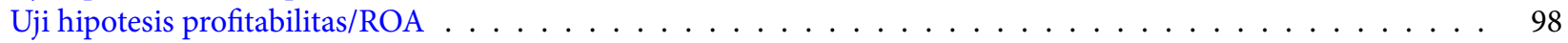

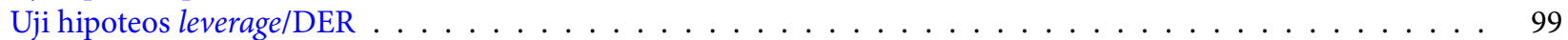

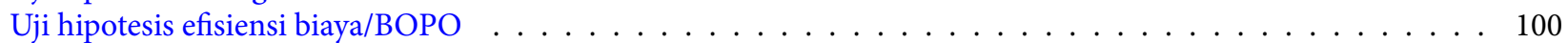

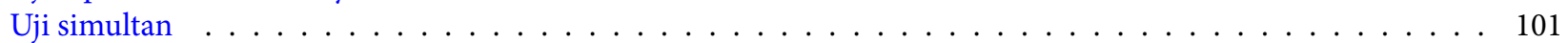


TABLE 1 | Uji hipotesis usia perusahaan/age

\begin{tabular}{|c|c|c|c|c|c|}
\hline \multirow[t]{2}{*}{ Model } & \multicolumn{2}{|c|}{$\begin{array}{l}\text { Unstandardized } \\
\text { Coefficients }\end{array}$} & Standardized Coefficients & $t$ & Sig. \\
\hline & $B$ & Std. Error & Beta & & \\
\hline age & .002 & .003 & .110 & .909 & .368 \\
\hline
\end{tabular}


TABLE 2 | Uji hipotesis ukuran perusahaan/size

\begin{tabular}{rlllll}
\hline Model & \multicolumn{2}{l}{$\begin{array}{l}\text { Unstandardized } \\
\text { Coefficients }\end{array}$} & Standardized Coefficients & $\mathrm{t}$ & Sig. \\
& $\mathrm{B}$ & Std. Error & Beta & & \\
size & .071 & .014 & .705 & 5.006 & .000 \\
\hline
\end{tabular}


TABLE 3 | Uji hipotesis profitabilitas/ROA

\begin{tabular}{rlllll}
\hline Model & \multicolumn{2}{l}{$\begin{array}{l}\text { Unstandardized } \\
\text { Coefficients }\end{array}$} & Standardized Coefficients & $\mathrm{t}$ & Sig. \\
& $\mathrm{B}$ & Std. Error & Beta & & \\
roa & .003 & .007 & .091 & .465 & .644 \\
\hline
\end{tabular}


TABLE 4 | Uji hipoteos leverage/DER

Model Unstandardized

Coefficients

B

der

Std. Error

Standardized Coefficients

t

Sig.

Beta

.053

.556

.581 
TABLE 5 | Uji hipotesis efisiensi biaya/BOPO

\begin{tabular}{rlllll} 
Model & \multicolumn{2}{l}{$\begin{array}{l}\text { Unstandardized } \\
\text { Coefficients }\end{array}$} & Standardized Coefficients & $\mathrm{t}$ & Sig. \\
& $\mathrm{B}$ & Std. Error & Beta & & \\
bopo & .000 & .001 & .059 & .285 & .777 \\
\hline
\end{tabular}


TABLE 6 | Uji simultan

\begin{tabular}{|c|c|c|c|c|c|c|}
\hline \multicolumn{7}{|c|}{ ANOVA $^{a}$} \\
\hline \multicolumn{2}{|c|}{ Model } & Sum of Squares & Df & Mean Square & $\mathrm{F}$ & Sig. \\
\hline \multirow{3}{*}{1} & Regression & .604 & 5 & .121 & 18.247 & $.000^{b}$ \\
\hline & Residual & .324 & 49 & .007 & & \\
\hline & Total & .928 & 54 & & & \\
\hline \multicolumn{7}{|c|}{ a. Dependent Variable: isr } \\
\hline \multicolumn{7}{|c|}{ b. Predictors: (Constant), bopo, der, age, size, roa } \\
\hline
\end{tabular}

